\title{
Kant's Revised Account of the Non-Moral Imperatives of Practical ReAson
}

\author{
LAURA PAPISH \\ George Washington University
}

\section{Introduction}

Kant's account of non-moral practical imperatives - specifically imperatives of skill and imperatives of prudence, ${ }^{1}$ which Kant collectively terms hypothetical imperatives and contrasts with the categorical imperative-has been receiving an increasing amount of attention in the literature. ${ }^{2}$ While interpretations of Kant's account, as well as the points at which it proves defensible and indefensible, remain matters of disagreement, some generalizations can be made.

Typically, and unsurprisingly, Groundwork 4:412-420 remains the locus classicus for reconstructions of Kant's view. Although Kant refers to imperatives of skill and prudence throughout his moral writings and in lecture transcripts, the treatment he offers in Groundwork II appears, of all his comments on these imperatives, the most representative as well as the most systematic, even if - as many commentators think - it's nowhere near as systematic as it should be. And, as this aside should indicate, it's also fair to say that assessments of Kant's account

1. A list of abbreviations is included at the end of this article. References to Kant's writings are cited in the body of the text and according to the volume and page numbers in Kants gesammelte Schriften. The only exception is the Critique of Pure Reason, where my citations follow the standard A/B pagination. References to Kant's Reflexionen also include the number assigned to them by Erich Adickes. All translations are from The Cambridge Edition of the Works of Immanuel Kant.

2. Thomas Hill's classic article "The Hypothetical Imperative" (1973) deserves credit for inaugurating this trend in the Anglo-American literature. Since Hill's article, attention to Kant's theory of the non-moral imperatives has continually increased, and this is due to both Kant's influence on contemporary theories of practical reason and interest in Kant's thought in its own right. For commentary that references Kant's own views, see, for instance, Wood (2013; 2014: 40-60), Timmermann (2007: 63-71), Allison (2011: 151-166), Korsgaard (1997), and Schroeder (2005). Concerning the vast contemporary literature on instrumental rationality inspired by Kant, examples are discussed in Footnotes 13, 14, 15, 36, and 39.

Contact: Laura Papish <laurapapish@email.gwu.edu> 
tend to be negative. It is widely agreed that Kant's treatment of the non-moral imperatives of practical reason is confusing, incomplete, and lacking the requisite argumentation (Timmermann 2007: 71; Wood 2014: 52).

I agree that Groundwork 4:412-420 fails to provide a clear and defensible account of the imperatives of skill and prudence. But while commentators tend to think this spells trouble for Kant's theory of non-moral practical imperatives more generally, and that Kant never really clarified his position in any significant way, ${ }^{3}$ on this point I differ. Groundwork II is problematic, but as I show in this paper, it is not Kant's final word on the non-moral imperatives of practical reason. In fact, there is substantial and broadly overlooked evidence that Kant later rejected core elements of the account he laid out in this text. This evidence is found primarily in the Introductions for the Critique of the Power of Judgment, and my aim is to explore this evidence. ${ }^{4}$ More specifically, I discuss the extent to which Kant's understanding of the non-moral imperatives of practical reason changes and the virtues of his later account.

\section{Groundwork 4:412-420: Relevant Textual Points and Controversies}

Before turning to Kant's account of imperatives of skill and prudence in the Groundwork, it is, for our purposes, necessary to call attention to how Kant situates his account.

Prior to Groundwork II, Kant's aim was to demonstrate that moral knowledge is implicit within common human reason. Once this is established, a transition to a more philosophical mode of moral cognition is required. To effect this transition, Kant begins by laying out a theory of the will, or the practical faculty of reason most generally (GMS 4:412-414). As he notes, the will is the capacity to act in accordance with the representation of laws. This definition holds for any possible will, whether a human being's or a divine will. But since only the former is not by necessity determined to act in accord with the objective laws that govern it, only human beings are subject to imperatives. In other words, only human be-

3. Those essays on Kant's theory of practical reason most generally - such as the essays by Wood, Hill, and Korsgaard-do not meaningfully engage the third Critique. Moreover, none of the scholarship that focuses more narrowly on the Groundwork and its account of non-moral imperatives notes that Kant, in the third Critique, revised his understanding of these imperatives. Any such reference is absent, even though it is customary in such commentaries to at least nod to significant, later developments concerning central issues in Kant's work. Finally, it is important to state that even if an author refers to some element of the third Critique, like Kant's re-labeling of "problematic" imperatives at EEKU 20:20on, such an observation on its own cannot count as significant engagement with the text. (I say more about EEKU 20:20on toward the end of Section 3.)

4. Complementary evidence in other texts is reviewed in Footnote 31 of this article. 
ings find themselves standing under objective laws that make commands, present an "ought" or a Sollen, and are necessitating, though not necessary.

From this point, Kant then differentiates between the types of imperatives that apply to us. But again, before we consider that discussion, it's importantfor reasons that will become clear later-to emphasize and historically contextualize the points reviewed thus far.

Before any mention of what specific objective laws the human will is subject to, or the different imperatives or types of "oughts" thereby expressed, Kant insists on the importance of giving an overview of the will, and then the human will, at the broadest possible level of conceptualization. The will, in the case of human beings, stands under an as yet unspecified range of objective laws that are experienced as presenting imperatives or oughts.

Moreover, this framing is not a one-off or dispensable to Kant's aims. Instead, it is a considered approach reiterated in other texts and materials from the same time period. Just as Kant, in the Groundwork, emphasizes that before we discuss the categorical imperative an account of the "general rules of determination" of the "practical faculty of reason" should be provided (GMS 4:412), the Collins and Mrongovius lecture notes from the same time period-1784-85start with the most general concept of a will that stands under objective laws and then shift to the more specific concept of a human will that experiences those laws as imperatives that express an ought (V-Mo/Collins 27:245; V-Mo/Mron II 29:588-589); only then can Kant later go on to subdivide the imperatives of practical reason into those of skill, prudence, and morality. Similarly, at crucial junctures in the second Critique, Kant leverages insights into how practical principles secure a "general determination of the will" in order to develop an account of moral obligation (KpV 5:19), and he relies on "practical reason in general" (KpV 5:66) as a "clue" that illuminates the determination of the will according to moral principles. ${ }^{5}$ Both the derivation of the categorical imperative and its contrast with hypothetical imperatives ( $\mathrm{KpV}$ 5:20), and Kant's notoriously opaque table of the categories of freedom ( $\left.\mathrm{KpV}_{5}: 66-67\right)$, require guidance from a preliminary account of the faculty of practical reason most broadly conceived.

It is further important to note that in prefacing his account of the distinct imperatives of practical reason this way, Kant makes it clear that he intends to both draw from and criticize the approach established by Wolff and Baumgarten. ${ }^{6}$ Baumgarten's Initia Philosophiae Practicae informed the first half of Kant's

5. See Lee (2012: 348). See also KrV A70/B95, where Kant refers to general logic as a "clue" for the development of transcendental logic. I say more about general and transcendental logic, and its relevance to this article, in Footnote 37.

6. I stay neutral on the question of whether Baumgarten's ethics was more influential than was Wolff's. For a positive defense of this claim, see Schwaiger (1999). 
lectures on moral philosophy, 7 and like both the Initia and Wolff's Philosophia Practica Universalis, these lectures always proceed by first outlining a "universal practical philosophy", or by placing moral philosophy into a wider discussion of the rules and laws of practice and action more generally. Kant, in echoing this move at Groundwork 4:412, shows his debt to these predecessors. But he also, as his discussion advances, balances this acknowledgment with criticism. Kant, in the Groundwork and these 1784-85 lectures, recognizes that practical reason in general must be treated before we develop an account of moral reason, but he breaks from Baumgarten and Wolff by insisting that the latter cannot be situated squarely or cleanly in an account of the former. Both philosophers failed to see the "dissimilarity" between moral and non-moral imperatives that would eventually need to be stressed in order for practical philosophy to be successful (GMS 4:416). ${ }^{8}$ Indeed, even with the resources of a general practical philosophy at hand, Kant warns that he will have to "break into an entirely new field" (GMS $4: 390) .{ }^{9}$

With these contextual remarks in place, we can now consider, as Kant himself does, the first set of imperatives human beings are subject to. As already noted, these are imperatives of skill and imperatives of prudence, which Kant alternatively refers to as "problematic" and "assertoric" imperatives (GMS 4:415-416), or, together and as noted previously, those imperatives that command hypothetically (GMS 4:414). Because certain points Kant makes regarding these imperatives, such as their alleged analyticity (GMS 4:417), are not immediately relevant to our concerns, ${ }^{10}$ and because numerous paragraph-by-paragraph commentaries on the Groundwork already exist (Timmermann 2007; Allison 2011), I'll assume that a thorough overview of Kant's remarks is unnecessary. Instead, I want to focus on why many find Kant's discussion of these imperatives of skill and prudence unsuccessful.

A chief failure of Kant's discussion is its inability to clarify whether there is something like a "Hypothetical Imperative" lurking in the background of his account of hypothetical imperatives. Though this criticism has, as we'll see, special implications in the context of Kant's claims regarding prudence and happiness, it applies both to Kant's account of the imperatives of skill, which specify the rules one must follow to secure the means to and thus realize any number of

7. This is widely noted, but see, for example, Bacin (2015).

8. On this point, I am indebted to Wood (2014: 60).

9. This is not only due to problems in Wolff and Baumgarten's theories of obligation. It is also due to their failure to appreciate that not all grounds of motivation are identical and that we must thereby differentiate between motivating grounds from inclination and motivating grounds from reason (V-Mo/Mron II 29:598). See also Bacin (2015: 23).

10. I do, however, say a bit more about the analyticity of hypothetical imperatives in Footnote 16 of this article. 
"discretionary" ends (GMS 4:415), and to imperatives of prudence, which provide the counsels that should guide a person as she wills-by "natural necessity" (GMS 4:416) - the end of her own happiness.

There are different and opposed ways we can interpret the imperatival character of these particular rules and counsels. For some, the setting of ends, whether an arbitrary end advanced through skill or the universally held end of one's own happiness, is a normatively significant act (Wood 2014: 50). If it is an essential characteristic of rational agency that setting an end commits one to the pursuit of the appropriate means, then we stand under a broad imperative of practical reason, one that Thomas Hill and Allen Wood agree should be referred to as the "Hypothetical Imperative" and that expresses the following command: "if a person wills an end and certain means are necessary to achieve that end and are within his power, then he ought to will those means" (Hill 1973: 429). ${ }^{11}$ Or, in contrast, we might understand Kant as saying that imperatives of skill and prudence are imperatives in an emaciated or minimalist sense and only insofar as they translate third personal descriptions of means-end relationships into statements that reflect our status as agents that do not, as a matter of empirical fact, always seek the means to their ends. ${ }^{12}$ As should be apparent, the crucial difference between this formulation and the more robust one described above is the willingness of Wood and Hill to argue that there exists a non-moral ought, or a non-moral and yet objective principle of practical reason. The minimalist reading would not permit this point. On the minimalist view, there is no "Hypothetical Imperative"; there are only hypothetical imperatives, and these are really only cause-effect statements coupled with the simple observation that human beings don't always seek the causes that promote the desired effects.

The above explains the two interpretative poles around which Kant's account of imperatives of skill and prudence has been read, though in practice, most commentators do not endorse without amendment the views at either extreme. Even though Wood and Hill are comfortable with the claim that there is a non-moral ought, this "ought" has, for them, a defeasible status in light of both how we might arbitrarily decide to abandon particular ends-at the least, our discretionary ends associated with skill - and the overriding character of the categorical imperative. ${ }^{13}$ Similarly, even Jens Timmermann, who endorses what

11. An important caveat to this command is introduced in the next paragraph.

12. Here I draw on Timmermann (2007: 66).

13. Once this point is noted, it becomes clear that Wood and Hill endorse what the contemporary literature on instrumental rationality would call a "wide scope" reading of the Hypothetical Imperative. To repeat Hill's formulation, the Hypothetical Imperative commands that "if a person wills an end and certain means are necessary to achieve that end and are within his power, then he ought to will those means". Since Hill (and Wood) will understand this as a command either to take the means to one's end or to abandon the end when the means or actions required 
I have labeled the minimalist interpretation of imperatives of skill and prudence, shifts a bit closer to Wood and Hill when he acknowledges, albeit briefly, that imperatives of skill and prudence will issue "all things considered rational commands" in cases where "reason announces the purpose in question worthy to be pursued" (Timmermann 2007: 69). Yet since an end that reason permits me to pursue is typically not one I am commanded to pursue, Timmermann's claim only makes sense if the sheer act of committing to an end puts a person under some form of rational constraint and generates some reasons for action. Though he doesn't recognize it, Timmermann's point amounts to a real concession to Wood and Hill. ${ }^{14}$

prove impermissible, they understand the "ought" in the imperative to have scope over the entire conditional-that is, a "wide" scope. This may be contrasted with a "narrow" scope interpretation of a non-moral imperative. On this interpretation, the "ought" has scope only over the consequent; thus willing an end of skill or prudence renders one rationally committed to take the means. For helpful discussion of the wide/narrow scope distinction, see Way (2010), Shpall (2013), Brunero (2010), Broome (2007), and Kiesewetter (2017). On Hill as advocating a wide scope interpretation, see Schroeder (2005: 358). I am grateful to the anonymous reviewer who suggested that I explore the connection between Kant and the current wide/narrow scope debate, and I reference some aspects of this debate in Footnotes 14, 15, 36, and 39. I restrict my comments about this contemporary debate to the footnotes of this paper due to difficulties in aligning it neatly with the Kant scholarship. These difficulties are discussed first in Footnote 14, and revisited in Footnotes 36 and 39.

14. It remains clear enough that Timmermann intended for his minimalist interpretation to be contrasted with any account that advocates, as the wide scope account endorsed by Hill and Wood does, an objective principle of practical reason beyond the categorical imperative. But in making the concession discussed here, Timmermann not only distances himself from his initial minimalist interpretation of Kant's non-moral imperatives. He also makes it difficult for us to see exactly what sort of view he intends to put in place of a wide scope reading of a Hypothetical Imperative. Taking a cue from the contemporary literature, note three possibilities. (1) After a wide scope interpretation has been rejected, some philosophers develop what may be called a "weakened" narrow scope view. In this case, narrow scopers proceed by re-interpreting the "ought" governing the consequent so that it will not generate a conclusive reason for action. They proceed, then, by weakening the force of the "ought" or otherwise reconceptualizing the sort of constraint we place ourselves under in willing an end (see Kiesewetter 2017: 83); Schoeder (2004) serves as a contemporary example of (1). (2) There is a more radical kind of narrow scope account, one that tries not merely to weaken the normative force of the instrumental principle but to establish instead that the non-moral ought is a fiction or a myth. Examples of a "mythic" narrow scope view can be found in the work of Niko Kolodny $(2005 ; 2007$; 2008) and Joseph Raz (2005). On their views, there is no reason why an agent should adhere to the instrumental principle, although, and rather peculiarly, there still is a rational requirement to achieve means-end coherence; hence it is a myth that this requirement has normative force, even though Raz and Kolodny still maintain that such a requirement exists. (3) Finally, after one has rejected a wide scope interpretation of a principle requiring that we take the means to our ends, it is not the case that the only option left is to seek refuge in a narrow scope interpretation along the lines of (1) or (2). It is also possible to dispel, altogether, the idea of a non-moral principle of practical reason. In doing so, one also dispels, altogether, the need to interpret such a principle according to the terms set by the debate about wide versus narrow scope (Kiesewetter describes but does not personally endorse this option; see Kiesewetter 2017: 20-22, 156-158). The view I will soon attribute to the late Kant aligns most closely with (3), and while Timmermann's interpretation of Groundwork II initially seemed to 
In light of this discussion, it is clear what a difficult position Kant at Groundwork 4:412-420 is in, as well as his readers. Regardless of which strategy one pursues for making sense of imperatives of skill and prudence, there is something only rival views can adequately clarify. Timmermann's inclination toward a minimalist strategy makes sense for several reasons. These include, as Henry Allison (2011: 165-166) has pointed out, how Kant never formulates a "Hypothetical Imperative" in anything like the precise manner Hill does and how Kant is far more inclined to describe various hypothetical imperatives than explain the "Hypothetical Imperative" as such. Yet only Wood and Hill can explain why Kant's discussion of imperatives of skill and prudence is situated in a broader account of practical, and not merely theoretical, reason. Kant's express aim, at 4:412-420, is to explain how the human will is, in general, guided by objective laws that can be expressed as imperatives and that are experienced by us as necessitating or constraining. To the extent that Timmermann adheres to his minimalist reading of hypothetical imperatives, he must read them as boiling down to a set of descriptive claims: a descriptive claim regarding how means and ends relate, and then a descriptive claim regarding the fact that human beings do not always take means to their ends. But from this, nothing whatsoever follows about constraint, necessitation, or objective principles of practical reason in its non-moral application. Timmermann cannot do justice to Kant's explicit strategy at the outset of Groundwork 4:412-420.

And, in something of a mirror image, Wood and Hill's reconstruction is weakest where Timmermann's is strongest. Timmermann rightly recognizes the treacherous territory Kant has stepped into if he is indeed arguing that there is a "Hypothetical Imperative" sitting behind specific imperatives of skill and prudence. To justify this claim, Kant would need to offer a derivation of the Hypothetical Imperative that resembles that offered for the categorical imperative. But Kant neglects to provide this. ${ }^{15}$ Instead of uncovering the grounds from which it follows that we ought to pursue the means to our ends, or why reason demands

lean in this direction as well, it can no longer fit this motif once his concession to Hill and Wood is made. I cannot speculate productively as to whether Timmermann would in the end align himself with (1) or (2), or try to craft a different response altogether.

15. Indeed, and as Schroeder (2005: 360) has pointed out, Kant should not provide this, as doing so would jeopardize his claim that only reason's moral principle can provide a categorical imperative. Note, moreover, that while Hill and Wood's wide scope interpretation of the Hypothetical Imperative-see Footnote 13 of this paper-can account for why an agent who wills an impermissible end is not immediately obligated to pursue its means, agents are nonetheless, on their interpretation, categorically commanded to either will the means or drop the end. Thus Hill and Wood's disjunctive or wide scope account of a Hypothetical Imperative cannot be endorsed without nullifying Kant's claim that the moral imperative is the only categorical imperative. For contemporary discussion of the categorical character of the instrumental principle under a wide scope interpretation, see Schroeder (2004: 349) and Lord (2011: 398). For these references, I am indebted to Kiesewetter (2017: 58). 
the pursuit of means, he simply states that when reason is decisively influential, volition of the means follows the volition of ends (GMS 4:417). ${ }^{16}$ Moreover, this failure occurs in exactly those passages where Kant claims he will explain the possibility of all practical imperatives, and exactly where readers tend to expect a defense of the principle that lies behind hypothetical imperatives (GMS 4:417-419). As Timmermann correctly recognizes, the only way to make sense of the text at this juncture is to see it as forcing us to abandon expectations for a justification of a Hypothetical Imperative, or a robust non-moral ought. Wood and Hill cannot do justice to how the text actually proceeds toward the end of Groundwork 4:412-420.

The implications of Kant's failure are extensive. It is left unclear how to understand, or self-understand, cases where an agent fails to secure the means to the ends associated with skill and prudence. It is also left unclear whether the allegedly assertoric character of the end of one's own happiness is, somehow, meant to address some of the difficulties with Kant's account of hypothetical imperatives and his lack of clarity regarding a Hypothetical Imperative. Kant's account of happiness as a necessary end can seem as though it is designed to pick up where Kant's explanation of the very possibility of hypothetical imperatives ends. As others have correctly noted, Kant, at some points, seems to view the necessity of happiness more as rational than as merely natural, that is, as something that human beings have reason to care about independent of morality. ${ }^{17}$ Given this, it appears that Kant might ultimately rely on the end of happiness to provide rational guidance: if we have a legitimate rational interest in happiness, and if happiness can fairly be interpreted, minimally, as requiring that we do not engage in self-undermining behavior like committing to the end of happiness but not its means, ${ }^{18}$ then perhaps the propriety of happiness for human beings is what accounts for the possibility of an objective principle of non-moral practical reason, at least in matters of prudence. But, as can easily be anticipated,

16. It is this statement-that when reason has decisive influence, the volition of means follows the volition of ends - that Kant refers to as an "analytic proposition" (for discussion see, among others, Hill 1973: 432). Unfortunately, however, this proposition provides no answer to the question of what normative backdrop, if any, such propositions must be understood against. That is to say, it is unclear on what basis reason makes this demand, or, alternatively, on what grounds we may establish that an imperative to take the means to one's ends is connected to the human will. In the lead-up to 4:417, the text primed us for a discussion of this issue. Yet to the extent that we do not find even an attempt at an account in 4:417ff., there is reason to favor instead an interpretation of hypothetical imperatives that renders this question moot. The minimalist reading initially suggested by Timmermann does this.

17. See, for example, Wood (2014: 56). For an attempt to defend the rationality of prudence independent of moral concerns, see Kain (2003).

18. Allison Hills (2006) argues for a view similar to this. I say more about Hills's view later in this paper. 
this strategy, if it is Kant's, will only cause further problems. It is highly unlikely Kantianism can accommodate the suggestion that there is anything like a "direct duty" to one's own happiness, or an immediate but non-moral ground for the oughts of prudential imperatives. ${ }^{19}$ And even if such a suggestion could be accommodated, it would do nothing to clarify whether there is indeed a Hypothetical Imperative in the background of those other hypothetical imperatives Kant speaks of, namely imperatives of skill.

We can conclude this section with a full appreciation of the disappointment commentators have registered regarding Kant's theory of non-moral practical imperatives in Groundwork 4:412-420. We can also see why, despite the best efforts of Wood, Timmermann, Hill, and others to make sense of these passages, a convincing interpretation and defense has not yet been found; the text really is more unclear and unwieldy than these authors allow. But as noted in the introduction to this paper, this is perhaps not as damaging to Kant as it may initially seem, if the Groundwork is not Kant's final word on the imperatives of non-moral practical reason.

19. On this point, see Timmermann (2007: 71). It may also help to highlight where Kant appears to go even further and warn against the possibility of a non-moral ground of rational necessitation. Despite Kant's introduction, at Groundwork 4:415, of imperatives of prudence into his account of the general rules of determination for the practical faculty of reason, the faculty tasked with accounting for the demand for happiness soon shifts away from reason and toward the imagination. In exactly those pages-Groundwork 4:417-419-where Kant fails to explain what principle lies behind either problematic or assertoric imperatives, Kant also, famously, claims that happiness is an ideal not of reason but instead imagination (GMS 4:418). He then further explains that since this ideal cannot provide a fully determinate principle of action, neither can it ground any imperative presumed to have the normative force of a law. So while the moral skeptic discussed at the very outset of Groundwork II believed that moral obligation was a "phantom of a human imagination" (GMS 4:407), it begins to look as though the oughts of prudence instead have this phantom or imaginary status. And if we aim to understand the risks of such phantoms, we may find guidance in Kant's account of illusion in the first and second Critiques, particularly comments regarding how an illusion stems from a pretense of objectivity. A mere appearance becomes a problematic illusion when, for example, we mistakenly attribute the scent and color of a rose to an object as it exists "for itself", thus forgetting that what is predicated holds "only in relation to the senses or in general to the subject" (KrV B70). In the practical domain, we have a propensity to let the "pathologically determinable self" present its claims as "primary and originally valid" (KpV 5:74). That is, one may impart to her or his self-love a normative sheen that allows the moral law to be displaced as the "unconditional practical principle"; with this, the agent capitulates to the "illusion" of self-conceit ( $\mathrm{KpV}$ 5:74). Against this backdrop, it is no surprise that one may be inclined to see the imperatives of prudence as necessitating, even when the ground of their necessitation is left unexplained. I am grateful to an anonymous reviewer for raising this issue and offering some extremely helpful reflections. 


\section{The Third Critique and Kant's Rejection of General Practical Philosophy}

As indicated, my argument is that in the third Critique, Kant articulates a view regarding non-moral practical imperatives that stands in contrast with, and amounts to a rejection of much within, the approach he tried in the Groundwork. However, before turning to the third Critique, we should place the failure of Groundwork 4:412-420 in the appropriate light.

As is widely recognized, the Groundwork's real aim was an elucidation of the categorical imperative, not a well-worked out overview of practical reason as such (see, e.g., Allison 2011: 158). But, more importantly, Kant clearly had some awareness that problems might arise from his attempt to situate moral reason within an overview of the faculty of practical reason in general. Even though, at Groundwork 4:413, Kant speaks of "all imperatives" as generating ought-claims and defines all imperatives in terms of how objective laws of reason stand in a necessitating relation to the human will, ${ }^{20}$ he also insists, when he pivots at 4:420 to a discussion of morals, that only the categorical imperative corresponds to an objective law or principle. Thus, despite Hill's claim that the Hypothetical Imperative is an expression of an "objective principle" of practical reason, Kant himself, at least toward the end of his main account of practical reason in general, warns that if a practical rule is not grounded in the way that moral commands are, it can never function as an imperative. ${ }^{21}$ Therefore, Kant's concerns about Baumgarten and Wolff's strategy to treat ethics as one topic among others within general practical philosophy, and about how to speak best about the demands of skill and prudence, play out in the open and are underway within, not merely post-, Groundwork.22 Furthermore, and relatedly, my argument will

20. He makes the same point at V-Mo/Collins 27:245.

21. Somewhat similarly, at V-Mo/Mron II 29:617, a bit more than 15 pages after Kant refers to a general practical philosophy and multiple grounds by which actions can become "necessary according to reason", Kant reminds us that pragmatic, or prudential, imperatives can never obligate. Indeed, even as early as the 1764 Inquiry Concerning Principles of Natural Theology and Morality, Kant, in the space of two pages, moves from the claim that an ought applies in the context of skill, and that oughts are associated with obligation, to a recognition that we should really only speak of a "formula of problematic skill" (UD 2:298-299). Otherwise, we risk implying that there is a non-moral species of obligation and that there can be practical necessity when our ends are not themselves necessary.

22. As further evidence of Kant's struggles with Baumgarten and Wolff, we may also consider how difficult it is for Kant, leading up to the Groundwork, to formulate a consistent terminological framework around which to discuss the distinction between moral and non-moral imperatives. As Schwaiger notes (1999: 181-182), while Kant "demotes" imperatives of prudence by claiming they provide only "rules" [Regeln] as opposed to "laws" [Gesetze] and restricting the latter term to morals (Refl 5235-5236/18:127; Refl 7821/19:526), Kant at points violates this distinction in both directions: he sometimes speaks of prudence as if it grounds objective laws (V-Mo/Collins 27:282) and sometimes speaks of ethics as if it contains rules (V-Mo/Collins 27:258). 
not depend on the claim that Kant's trajectory toward a more adequate account is uniform. The current tasks are only to demonstrate that there is a more defensible account of the imperatives of skill and prudence and to identify a particularly sharp statement of a revised approach in the Introductions to the third Critique. ${ }^{23}$ It will be shown that even if the pre-1790 works reveal the strain that Wolff and Baumgarten's framework wrought on Kant's practical philosophy, ${ }^{24}$ these Introductions give the first explicit notice that core features of his earlier account of the non-moral imperatives have been abandoned and, moreover, that a better alternative must be articulated. And as we move forward, it will become evident not only that Kant has changed how he introduces or frames an account of hypothetical imperatives. We will see also that this change prefaces a new, substantively different account of how to understand these imperatives. ${ }^{25}$

Kant begins both his initial and final drafts of the Introduction to the third Critique with a division of the different branches of philosophy or, equivalently, the different ways we can develop an organized system of rational cognition. ${ }^{26}$ The types of philosophy are theoretical and practical philosophy, and

23. Though as mentioned earlier, I discuss in Footnote 31 where else we might look for further support of the claim that Kant's account of the non-moral imperatives changes.

24. Since it is only with the third Critique that we can assert confidently that and how Kant's approach has shifted, it is not helpful to include in the body of this article a sustained discussion of the non-moral imperatives in the second Critique (KpV 5:19-21). I did comment briefly on this work a bit ago, noting that one finds at its outset another direct echo of Baumgarten and Wolff, as Kant again drew on the tradition of beginning with a universal or general practical philosophy and then situated within it the imperatives of skill and prudence ( $\mathrm{KpV}$ 5:19; see also Section 2 of this article). This is, however, not the only continuity with the Groundwork, as the second Critique treatment of the non-moral imperatives is mixed and frustrating in much the same way that it is in Groundwork II. Kant maintains, at one point, that "hypothetical imperatives" are "indeed practical precepts but not laws", and he also emphasizes that any such precept contains "only a subjectively conditioned necessity" (KpV 5:20). Such comments show the extent to which Kant, as he did in Groundwork II, endeavored to create distance between the non-moral imperatives and the categorical imperative. And given these comments, one might hope to find at KpV 5:19-21 a meaningfully revised and defended account of the imperatives of skill and prudence. But that hope is quickly dashed. Kant does not, for example, explain what a merely "subjectively conditioned necessity" is. He insists that "any rule that is to contain necessity" can arise only from reason "alone" (KpV 5:20), yet it is unclear how the faculty of reason can provide a subjective ground of necessitation that is not also, and foremost, an objective one. Kant also fails to reconcile his argument that hypothetical imperatives contain only subjectively conditioned necessitation with his claim - within the very same page of the second Critique - that every imperative is a rule "indicated by an 'ought', which expresses objective necessitation to the action" (KpV 5:20; my emphasis). As KpV 5:19-21 offers no deep clarification or clear amendment of Groundwork II, it can thus be put aside.

25. In other words, while Kant's works, prior to 1790 and as far back as 1764 (see Footnote 21), show him aware that problems arise when hypothetical imperatives are included in a general practical philosophy, these earlier texts do not indicate how, in the third Critique, Kant's eventual attempt to resolve these problems will proceed.

26. As is fairly well known, Kant claimed that the introduction initially drafted needed revisions simply because it was too long. See, for example, Critique of the Power of Judgment (Kant 2000: xlii) and page 582 of Ernst Cassirer's editorial notes for Immanuel Kants Werke, Band V (Kant 1914:

Ergo vol. 5, no. 11 2018 
Kant consistently carves out the distinction between them by referring us to the determinate objects of each discipline and the laws governing those objects (EEKU 20:195; KU 5:171). Theoretical philosophy concerns the objects of spatiotemporal experience, such as a given chair or the trees outside my office, and objects such as these are governed by laws of nature. These laws of nature can be universal laws that govern any natural object whatsoever, such as the law that every event-every inch that the chair is moved or every bit the leaves are shaken-has a cause, or these laws can be more concrete or localized, such as a law that governs the growth rate of an oak tree. ${ }^{27}$ Practical philosophy, on the other hand, has as its objects morals, which are governed not by laws of nature but instead by laws of freedom.

Of course, reliance on this contrast between theoretical and practical philosophy as a starting point is not unique to the third Critique. It is centrally featured in materials that predate 1790. Kant begins both the preface to the Groundwork and the Introduction to the second Critique with the same contrast while additionally noting logic - which I'll soon revisit-as a branch and emphasizing the roots of these distinctions in Ancient Greek philosophy (GMS 4:387 and KpV 5:15); he likewise refers to this set of contrasts at the outset of his lectures on ethics. ${ }^{28}$ But what is distinctive to the third Critique, as compared to these other texts, is Kant's decision to not soon append to practical philosophy or a doctrine of morals a consideration of the will most generally. In contrast to these earlier texts, the third Critique does not contain a discussion of practical reason that includes its non-moral application and practical reason's most general rules of determination.

In fact, and even more strikingly, the third Critique marks the first time that Kant expressly warns of a "great misunderstanding" we need to ward off. The misunderstanding, he says, would be to think that any use of reason other than its moral use belongs to practical philosophy (EEKU 20:195). That is, it would promote a misunderstanding to imply exactly what seemed implied by those pre1790 texts where he followed Baumgarten and others who include a lengthy discussion of universal or general practical philosophy. It would also, then, promote a misunderstanding to not clarify what should have struck readers as a peculiar juxtaposition of philosophical methods in texts such as the Groundwork and the second Critique. If, as Kant uniformly maintains in the beginning of these works, morality is the only science constitutive of practical philosophy, then

582). I will not engage the question of whether, in fact, length is the sole significant difference between the two Introductions, though I will note that Zammito (1992: 263-266) sees substantive shifts in at least Kant's tone and interests.

27. For helpful discussion, see the editor's introduction to Critique of the Power of Judgment (Kant 2000: xxiv).

28. See, for example, V-Mo/Collins 27:243-245 and V-Mo/Mron II 29:597. 
how do we make sense of Kant's exploration of generic rules for the determination of the will, which abstract from the possibility of an unconditional moral law and the capacity for moral motivation? In other words, how, if there can be no philosophical approach to or systematic conceptualization of practical reason in its non-moral use, are we to understand imperatives of skill and imperatives of prudence? The Introductions to the Critique of the Power of Judgment address these questions.

We can consider imperatives of skill first. Kant acknowledges that there are, to be sure, numerous disciplines that "contain a great many practical propositions" (EEKU 20:196). Diplomacy, home economics, etiquette, and practical geometry are all disciplines or arts that direct agents to do a certain thing in order to achieve established objectives, such as being respected by other statesmen, running an efficient household, maintaining customs of address and personal interaction, or constructing a square with the tools of given lines and right angles (EEKU 20:196; KU 5:198). Yet even though the objects constitutive of each of these disciplines can issue a set of practical directives, this does not suffice to bring these objects and their correlative disciplines under the heading of practical philosophy. Kant explains that,

while practical propositions certainly differ from theoretical ones, which contain the possibility of things and their determination, in the way in which they are presented, they do not on that account differ in their content.... [These propositions] are nothing more than theory of that which belongs to the nature of things, only applied to the way in which they can be generated by us in accordance with a principle. (EEKU 20:196)

There are, certainly, notable differences between theoretical propositions and practical propositions concerning, for example, diplomacy: we can distinguish between an object like a chair and an object, or objective, like diplomatic success, which concerns the existence of a certain state of affairs and not a spatiotemporal thing. Furthermore, the natural laws that apply to an object of experience such as a chair are predictive in a way that the rules governing some skills, such as those that advance international relations, are not, as we can hope for no more than counsels or generally reliable advice concerning what actions will bring a leader respect or increase the likelihood of peace. Nevertheless, practical propositions concerning diplomacy and the more obviously theoretical propositions concerning the properties of the chair both contain, as Kant says, "nothing more than the theory of that which belongs to the nature of things". The chair and relations between governments both exist only in the natural world, and both, albeit at varying degrees of certainty and specificity, are governed by natural laws concerning causes and effects. Just as applying sufficient force to the chair will 
cause it to move or break, following the traditions of address in a foreign country will likewise effect the end of diplomacy. And so both propositions concerning objects of experience and objects such as a geometrical representation or a treaty belong within what Kant calls a "philosophy of nature", whereas "only those propositions which give the law to freedom ... alone ground a special practical philosophy" (EEKU 20:197).

On the basis of these points, it so far seems that in the third Critique, Kant is leaning toward the minimalist understanding of hypothetical imperatives of skill that we considered in the context of Groundwork II. This proposal can only be tentative until we explore whether, elsewhere in the third Critique, Kant says anything to clarify whether there is something like a "Hypothetical Imperative". But if we start with the question of whether imperatives of skill form a subset within a general practical philosophy, and thus whether on their basis one can develop a practical philosophy that includes more than a doctrine of morals, it would appear that Kant's answer is no. Imperatives of skill exist as a part of theoretical philosophy, and thus it seems that an account of imperatives of skill must rely strictly on those naturalistic concepts provided by such a philosophy. In this case, imperatives of skill indicate only that there are cause-effect relationships between ends and means, and that human beings will secure their ends only by minding those relationships.

That Kant is inclined toward this minimalist interpretation is further made clear by his insistence in the third Critique on a terminological change. The third Critique, as is well known, is where Kant argues that while he previously referred to imperatives of skill as problematic imperatives, they should instead be called "technical imperatives" (see, e.g., Schwaiger 1999: 174; Wood 2014: 47). The reason Kant gives for the change is that there is a contradiction lurking in the notion of a problematic imperative, or an imperative applying to that which is at the discretion of an agent (EEKU 20:200). But another, ultimately complementary way to appreciate this shift is to notice how it forces us to rethink what it means for a human being to be concerned with imperatives of skill. The notion of a "problematic imperative" emphasizes the relationship between a human being and an objective law, or the conditions under which an imperative applies to us. The notion of a "technical imperative", by contrast, emphasizes that human action must in general be governed by technique, or the artifice exhibited by a craftsman. Just as the craftsman must rely on a set of instructions that enable him to create an object that matches his initial conceptual representation of that object, so must statesmen and practical geometers rely on poietic mechanisms if they wish to get anything done; 29 technical imperatives, as Kant says, detail merely "the manner of the execution of the end" (EEKU 20:200n).

29. On technique, see Zammito (1992: 132-133) and Zuckert (2007:115). 
We can now address imperatives of prudence or pragmatic imperatives. Kant is explicit in the third Critique that such imperatives should really be considered kinds of technical imperatives. Now, such imperatives are, Kant admits, cloaked by a special layer of indeterminacy. Unlike the disciplines of statecraft and practical geometry, prudence requires not only the explication of specific means but also a further determination of the end itself (EEKU 20:200). Whatever definition of happiness we might give, and no matter how invariant the pursuit of it is for human beings, a concrete specification of the ends constitutive of happiness will vary. But, nonetheless, pragmatic or prudential imperatives still concern the technical management of means that enable us to create the object that corresponds to our concept or ideal of happiness. And if all technical imperatives belong within the philosophy of nature, then the art of prudence must likewise be annexed from practical philosophy. This reinforces the argument that Kant is eliminating the possibility of a general practical philosophy, since no possible subject matter seems to remain for it.

In many respects, Kant's claims about the natural content of the practical arts and how the laws that govern their application are laws of cause and effect will strike us as perfectly acceptable and perhaps not even very surprising. But we might still wonder why these arts and their associated technical imperatives should be included entirely within a philosophy of nature. More specifically, we might wonder why practical disciplines do not constitute a sort of hybrid case. For while these disciplines have natural content and follow natural laws, they seem also to have a uniquely practical dimension. When I engage in diplomacy or try to bring out my own happiness, there would seem to be, after all, a certain norm of agency that binds me. This would be either the norm specified by the Hypothetical Imperative, or perhaps, those grounds on which a human being has a legitimate rational concern for happiness. If it is a normatively significant act to set ends, and if a human being has reasons independent of moral ones to facilitate her own happiness, then it would seem that there is an irreducibly practical component to the pursuits of diplomacy or prudence. As discussed in the previous section, there are arguments in the Groundwork that speak to the possibility of such non-moral norms or objective principles of non-moral practical reason. Does Kant say anything in the Critique of the Power of Judgment regarding this prospect? ${ }^{30}$

30. In proceeding to the next section of this paper, it is important to mention that some of the textual points I've just covered have at least been pointed out by other commentators. Carl Stange (1900), for example, also references Kant's claim that all technical imperatives belong to theoretical philosophy, but since he is more interested in the question of what significance this claim has for Kant's definition of an imperative, the distinction between imperatives and laws, and the import of these issues for Kant's treatment of the categorical imperative, he does not push, as I do, on the implications this claim has for Kant's broader accounts of instrumental and prudential reason. Moreover, and crucially, because Stange's account is not pushed in the direction that mine is, his 


\section{Non-Moral Norms in the Third Critique}

I will now argue that in this text, Kant indicates the inadmissibility of a nonmoral norm - whether the Hypothetical Imperative, or a foundational norm of prudence - in an account of human rational agency.

To reconstruct his argument, I will begin by noting that when Kant explores his division of rational cognition into a theoretical philosophy of nature and a moral philosophy, he appears to maintain that this division must be adhered to - and adhered to all the way down, so to speak - in any systematic inquiry whatsoever. Physics and ethics provide mutually exclusionary frameworks; they are the two aspects under which we can understand any given object, any given event, and the laws governing them. Even the will, or the faculty of desire, must be treated as either an object of nature governed by deterministic laws of cause and effect or as the seat of a capacity to act according to laws of freedom. It is essential to not leave "indeterminate" whether "the concept that gives the rule to the causality of the will is a concept of nature or a concept of freedom" (KU 5:172), and, crucially, whether an end is associated with a philosophy of nature-as are the arbitrary ends of skill and the assertoric end of one's own happiness-determines, for Kant, what conceptual framework applies to an analysis of the will itself.

To demonstrate his approach, consider the following claim Kant makes about the will insofar as it seeks its own happiness. He says that in such a case, we are guided by practical precepts that

concern the voluntary production of a certain state of mind in us (e.g. that of the stimulation or restraint of the imagination, the gratification or weakening of the inclinations). There is no practical psychology as a special part of the philosophy of human nature. For the principles of the possibility of its state by means of art must be borrowed from those of the possibility of our determinations of the constitution of our nature... (EEKU 20:199)

article was unequipped to deal with the challenge that I am about to address-namely whether we shouldn't simply see the practical arts and their associated imperatives as forming a sort of "hybrid" case where theoretical and practical philosophy overlap. This failure is significant, since with Stange neither addressing nor even noting this challenge, Konrad Cramer (1972: 176) and Konstantin Pollok (2007: 68) can later take it as a given - and without any real engagement with the third Critique as a whole or its Introductions - that Kant's intent in the third Critique was to advocate for a hybrid treatment of non-moral practical reason. In the remainder of this paper, and as I establish evidence against a hybrid reading of non-moral practical reason, it becomes clear why Cramer and Pollok's proposal is untenable. 
Kant, in this passage, clearly encourages us to think about the acquisition of one's own happiness as a mere engineering problem. There is no indication whatsoever that the subject should conceptualize herself as being necessitated to conform to a non-moral norm that gives her own happiness a basis in reason. On the contrary, Kant claims that there is no sense in which our self-understanding should unfold as an exercise in practical psychology. Instead of seeing our intentions and states of mind as subject to a law of practical reason, a person is to treat herself in the pursuit of happiness as if she were a natural thing, something that can be technically manipulated in the same manner that diplomatic relations or lines and right angles are. Happiness, as Kant says, presents "exactly the same" kind of problems as those found in mechanics, since in both cases the human being must simply investigate scientifically the character of the subject in question so as to achieve the correct states of equilibrium and contentment (EEKU 20:196). Just as the generation of ends associated with technical imperatives belongs to a philosophy of nature, "voluntary action" associated with such imperatives "belongs among natural causes as well" (EEKU 20:196). Therefore, when executing "technically practical rules (i.e., those of art and skill in general, as well as those of prudence)", "even the will (as a faculty of desire, hence as a natural faculty)" must be treated as "determined through natural incentives in accordance with those rules" (KU 5:172). Or, as Kant also puts it, the doctrine of happiness-understood to include both those precepts that secure one's objects of desire and an account of the principles governing "mastery of the inclinations and control of the affects" (KU 5:173) - belongs as little to practical philosophy as do formulae of practical geometry or a set of imperatives regarding the best agrarian practices (KU 5:173).

Since this is the sum of what Kant attempts to say here regarding the end of one's own happiness, he clearly seems to direct us to the conclusion that nature and freedom form antithetical philosophies at every level of description. Nonmoral ends like happiness belong to the philosophy of nature not only because these natural ends are governed by natural laws, but also, Kant argues, because the will itself must be thought to take on the quality of a natural object insofar as it seeks these ends. It would be a violation of the exclusivity between a system of cognition according to nature and a system of cognition according to freedom to understand oneself otherwise. There is no further point of view from which we can investigate the will, and consequently, pace the strategy Kant tried in texts such as the Groundwork, no generic or non-moral rules governing its rightful determination.

The Introductions to the third Critique thus provide evidence that no account of non-moral agency can or should include reference to a norm of prudential reason. Now, since Kant is explicit in these Introductions that imperatives of 
skill and prudence are fundamentally identical-as noted previously, both are placed in the category of technical imperatives - it would also seem that all nonmoral action should get the same diagnosis. If the only appropriate account of the end of happiness is one that conceptualizes a person's pursuit of it in thoroughly naturalistic terms, then actions meant to secure the arbitrary ends associated with skill require the same treatment. A foundational instrumental norm, or a "Hypothetical Imperative", cannot belong in an inquiry into technical imperatives, since Kant insists that an analysis of action in accord with such imperatives is conducted by theoretical philosophy alone. Nature is the domain of laws that causally determine events and actions with necessity, whereas the space of practical reason provides, for human beings, only a moral law that necessitates; thus technical imperatives, and human action that proceeds in accord with such imperatives, can be given only the kind of exposition used to clarify problems of physics.

To further defend this reasoning, we can note that while Kant does not, beyond what I've already covered, say much more about the ends of skill and prudence or their associated imperatives in the beginning of the third Critique, there are other places we can look for further explication of his position. An obvious place, and the one I will focus on in the body of this paper, ${ }^{31}$ is the remainder

31. Though I briefly mention Anthropology from a Pragmatic Point of View in Footnote 40 and in Section 5, Kant's anthropological writings, lectures, and reflections leading up to and from the time period of the third Critique are not generally helpful, since while Kant does speak of matters of skill and prudence throughout these materials, he only once uses the term "imperative" in them (Refl 1044/15:467); for a similar point, see Schwaiger (1999: 113). There is also not much assistance provided by Kant's Reflexionen on ethics. They are too brief to shed meaningful light on how Kant's thinking with regard to non-moral imperatives develops, although they do document an increasing tendency to rely on a twofold distinction regarding imperatives (morally practical vs. technical or technically practical imperatives) in place of the threefold distinction of imperatives (imperatives of skill, imperatives of prudence, and a categorical imperative) found in earlier texts such as the Groundwork or the second Critique. On this point, contrast, for example, Refl 7207/19:285 and Refl 7321/19:316.

I do not discuss at length the 1793-94 Vigilantius lectures, as these seem to contain - as any teacher would expect-an amalgamation of Kant's new and old methods for outlining hypothetical imperatives and are thus difficult to position neatly within Kant's corpus. For example, while at V-MS/Vigil 27:482 Kant's relies on his later twofold contrast between different types of imperatives in place of the earlier threefold distinction of imperatives and offers especially strong criticisms regarding Baumgarten's attempt to establish a "binding norm" in each of the "practical disciplines" (V-MS/Vigil 27:517), at other points Kant seems to revert back to his earlier views regarding non-moral imperatives and the possibility of offering a general practical philosophy. Thus, for example, Kant continues to rely on the concept of "problematic imperatives", even though, and as mentioned earlier in this paper, he criticizes this term at EEKU 20:200n for being contradictory (VMS/Vigil 27:486 and V-MS/Vigil 27:491). Furthermore, while Kant censures Baumgarten for thinking there can be a binding norm of practical reason where moral necessitation does not exist (see again V-MS/Vigil 27:517; see also V-MS/Vigil 27:489), he also speaks affirmatively and repeatedly about the possibility of non-moral oughts and non-moral necessitation (see V-MS/Vigil 27:485-6 and V-MS/Vigil 27:488). 
of the third Critique itself. Though it is not his focal point, Kant does say quite a bit about happiness and about skill in the last sections of the Critique of the Teleological Power of Judgment, sections that were written during the same short time period (May 1789 to March 1790) in which Kant drafted the first and final Introductions to the Critique. ${ }^{22}$ Of course, these sections have a life of their own, as they are indispensible to Kant's eventual moral proof for the existence of God. But if caution is exercised, remarks made toward the end of the book can be read as both setting up its conclusions and continuous with themes emphasized in the beginning.

In Section 83, Kant asks what, now that it has been established that nature can be judged as if it constituted a teleological system, the "ultimate" and "final" ends of that system should be; respectively, these ends correspond to what na-

Finally, I will make a brief note about the most obvious place we would look to confirm a shift in Kant's post-1790 approach to imperatives of practical reason, namely the Metaphysics of Morals. Although there are longstanding questions regarding Kant's state of mind as he composed the book and the extent to which the text has been corrupted, I will put both worries aside; the second one I put aside because regardless of which of the most recent editorial practices we followBernd Ludwig and the editors of the Cambridge Edition have different takes regarding the issue of corruption (Ludwig 1988: 49-59; Kant 1996d: 355-357) - no one has advocated rearranging or otherwise changing the initial eight paragraphs of Section III of the Introduction to the Metaphysics of Morals, which is where Kant introduces the notions of an imperative, of duty and other key concepts.

Given our purposes, the heading of Section III should immediately spark our interest. Kant frames his discussion as an overview of the "preliminary concepts of the metaphysics of morals", and puts as his parenthetical subheading "philosophia practica universalis" (MS 6:221). Now, this reference to Wolff's text of the same name might make it seem as though Kant intends to recycle the generic approach to practical reason that he used in texts such as the Groundwork and the second Critique. But as one reads Section III, it becomes clear that Kant is not recalling his earlier methodology. First, to whatever extent there is a generic overview of practical reason here, it is general not because it includes any account of a Hypothetical Imperative or a norm of prudence. Rather, the discussion is universal or general insofar as it details concepts relevant to both moral and political philosophy; instrumental and prudential reason is almost entirely absent from the discussion. Second, though Kant very briefly discusses non-moral imperatives, he is completely consistent in his use of post-third Critique terminology. He does not once use the notion of a problematic imperative or even refer to "hypothetical imperatives", and he stresses that all non-moral imperatives are mere technical imperatives or "precepts of art" (MS 6:221). There is no reference whatsoever in these passages to ends and means, let alone an account of that relationship in terms of practical necessitation or even volition. Finally, while Kant spoke of needing to address the possibility of hypothetical imperatives in the Groundwork, and thus implied that there is a Hypothetical Imperative or a foundational norm of prudence, he is perfectly explicit at MS 6:222 that it is only for the categorical imperative that we need to find the ground of its possibility. All told, then, the Metaphysics of Morals confirms strongly the approach to non-moral imperatives developed in the Introductions to the third Critique.

32. For an overview of this chronology, see Zammito (1992: 4-8). Drawing on the broader literature regarding the development of the third Critique, Zammito dates the First Introduction to just before, or no later than, May 1789 and the published Introduction to March 1790. In between these dates, Kant constructs the Critique of Teleological Judgment and a few other sections regarding aesthetic judgment. 
ture, as a closed system, can be thought to aim for and what stands outside the system of nature and is thus capable of providing the raison d'etre for nature as such. ${ }^{33}$ After recognizing that the human being, with its unique capacity to set ends, must exist as the ultimate end of nature, Kant then addresses, more specifically, through what vocation we are rightly thought to deserve this special place. He settles on the answer that the ultimate end of nature can be found in the human capacity to develop a culture of discipline with regards to inclinations, but more important for our purposes is his elimination of two other possibilities: that the ultimate end of nature is human happiness, and that the ultimate end of nature is the development of skill, or the development of capacities that facilitate a wide range of human endeavors. In explaining why these two other candidates must be eliminated, Kant reveals something else that is important. More precisely, it becomes clear that the normative demands we are ordinarily inclined to associate with ends of skill and happiness only make sense if we rely on certain unsubstantiated assumptions regarding them.

Consider Kant's especially deep cynicism regarding happiness. He reiterates not merely the oft-repeated Kantian point that a given person's ideal of happiness is indeterminate and fluctuating (GMS 4:399, 4:418). He also makes it clear that even if a person's conception of happiness were stable and concrete, this wouldn't change or elevate its significance in either human life or nature more generally. The reason is that even when a person firmly settles, in advance of action, precisely what she wants, she will be unsatisfied with it once she secures it. As Kant argues, the "nature inside us" is in general "not receptive" to happiness, or, equivalently, man's "nature is not of the sort to call a halt anywhere in possession and enjoyment and to be satisfied" (KU 5:430). ${ }^{34}$ This inability to be satisfied holds even if a person tries only to fulfill "genuine natural need" and even if he or she tries only to develop talents rather than secure specific goods (KU 5:430).

Kant relies on these insights to explain why human happiness is not the ultimate end of nature. But these points are also highly relevant to the topic of this article. For if this is how the dynamics of happiness in human life work, then the explication of either a norm of prudence or a Hypothetical Imperative becomes highly implausible. If Kant is right that we have such a deep disposition to be

33. This way of putting the distinction is my own, but I am indebted to Wood (1999: 309) and Guyer (2005: 189).

34. It should be no surprise that Kant says this about human nature, since he notes in the Anthropology that pain functions as a "goad to activity" (Anth 7:234). As is clear in this section of the book, were human beings fully satisfied with the realization of their ends, they would feel a lifelessness that is experientially proximate to the feeling of death. It is therefore essential to the human condition that we feel dissatisfied with the ends of desire, once we secure them. On Kant's theory of pain in relation to human action and Kant's theory of pleasure, see Papish (in press: Chapter 1). See also Meld Shell (2003). 
unsatisfied with ends once we realize them, then productivity within nature goes hand in hand with personal futility. In this case, any reasonable contender for what a norm of prudence would demand becomes inapplicable to human beings. For example, some, such as Alison Hills, have tried to argue that Kant does believe in a prudential principle and that it directs each person to limit the pursuit of a given end if it does not cohere with "the sum of her other desires" (2006: 254). Yet for Hills's view to work, it is not enough that, from an abstract or technical standpoint, happiness can be an attainable, harmonious whole so long as we refuse to act on certain inclinations. It is necessary, from the human being's own point of view, that volition is structured such that this balanced sum would in the end remain, with at least some reliability, an object of desire after it is secured. Absent this element of stability, it is implausible that there is as an objective principle of reason expressed as the demand that we must strive to form a harmonious arrangement of empirical ends. Moreover, much of this argument holds mutatis mutandis for an inquiry into the possibility of a Hypothetical Imperative. There cannot be an objective principle of reason that we ought to pursue the means to our ends unless the means lead, with at least some reliability, to the object as we desired it. Yet, as just shown, in at least the case of happiness, this connection does not hold.

If we consider Kant's comments regarding skill in Section 83, we find claims that only add to the difficulty of establishing a foundational instrumental norm. Kant maintains that skill, and a culture of skill, cannot be regarded as the ultimate end of nature, and his argument for this claim proceeds roughly as follows. In this context, skill is regarded by Kant as a class-centered and technologically driven undertaking; we are to imagine, as an example of the cultivation of skill, not an individual person becoming better at fishing but much broader advancements across industries and modes of production. Such advancements, however, are not presented as either evaluatively positive or neutral. They are asymmetrical in whom they benefit and who is supposed to do the difficult labor, with the majority forced into a "state of oppression, bitter work and little enjoyment" and the luxuriating minority receiving the goods of this labor in exchange for gentle work in "less necessary" domains of "culture, science, and art" (KU 5:432). Given the antagonistic and, ultimately, war-prone character of a culture of skill, Kant observes that no such culture can be judged as the ultimate end of nature.

Now, the implications of the above claims for Kant's theory of non-moral imperatives are rather more removed than were those that followed from the claims he made about happiness. In part, this is because the collective dimension of skill is more prominently underlined than is the collective dimension of happiness; the more Kant's focus is on collective dynamics, the more difficult it will become to see its relevance for a theory of how each individual person is constrained, or necessitated, by the faculty of reason. But this discussion nonetheless reveals 
a challenge that would have to be addressed-and yet is not addressed-were there to exist something close to Hill's proposed Hypothetical Imperative in Kant's practical philosophy. The challenge is as follows: The acquisition of ends achieved through skill brings with it grave and widespread unanticipated consequences, and yet that unpredictability is not adequately addressed by proposals to establish in Kant's philosophy a foundational instrumental norm.

Another way to put the challenge is as follows. Most frequently, commentators proceed by showing the applicability of the Hypothetical Imperative in isolated and simple cases: Hill (1973: 432) gives an example of someone who has set the end of getting new tires on a car, and Wood (2014:49) notes someone who has the intention of making a good impression on the first day of a new job. It is not typical to question, when these examples are presented, whether the end in question will remain an object of desire once secured. There isn't generally much harm that follows from getting new tires, or from making a good first impression, and so it seems unquestionably rational to acquire the means to one's ends. But what Kant's discussion regarding skill in the third Critique demonstrates is that not all ends have this character. A Hypothetical Imperative is most plausible under the assumption either that unforeseen consequences are generally negligible or that we will still regard our ends as objects of desire when we see them juxtaposed with their unforeseen consequences. Yet unless one of these assumptions is explicitly defended, 35 the rationality of the demand to secure the means to one's end is questionable. And since Kant's discussion of whether skill is nature's ultimate end includes a forceful challenge to both assumptions, it can be counted as evidence that Kant is unconvinced, at least in the third Critique, of the legitimacy of a Hypothetical Imperative. ${ }^{36}$

35. Or unless it is somehow argued that non-moral reason is supposed to be as invulnerable to such empirical findings as moral reason. But if this argument were made, then Kant's ability to demonstrate the distinctiveness of a categorical imperative would be badly impaired.

36. Given the arguments of this section, we can see that there is some affinity between Kant's revised account, which casts doubt on the possibility of a Hypothetical Imperative, and the contemporary work of Kolodny (2007: 258) and Raz (2005: 19), who view the idea of an independent, normative reason-or a reason "as such" - to avoid practical incoherence as a myth or fiction. I comment further on this affinity in Footnote 39, but at present it is important to highlight the difference between their views and Kant's. Recall from Footnote 14 that while Kolodny and Raz deny the normativity of instrumental rationality, they do not deny that instrumental requirements exist. Each claims that there are indeed within practical rationality certain requirements, even though, in their parlance, we have "no reasons to be rational" (Kolodny 2005: 452; Raz 2005 relies on similar locutions throughout). This is the juncture where it becomes clear that their view cannot align with Kant's own. Within Kant's corpus, there is no space for the idea of a requirement that is practically rational but not reason giving. That is to say, there is no indication that, when considering what it means for some demand or requirement to issue from reason, we can splice Vernunft, or the concept of what is vernünftig, so that it sometimes gives us what Kolodny or Raz deems "rational" and other times gives us what they would deem "reasonable" or normative. Thus while Kolodny and Raz offer, as discussed in Footnote 14, a mythic narrow scope interpretation of principles of 


\section{Concluding Defense of Kant's Theory of Non-Moral Imperatives in the Third Critique}

To bring this article to a close, I will consider, however briefly, a couple remaining grounds for questioning the conclusion reached in this article.

First, while the above comments show that Kant's doubts about both a general practical philosophy and non-moral practical norms are not as ill-conceived as some contemporary readers might initially suppose, there is another angle from which one could challenge my reading. I have in mind how Kant himself draws a parallel between logic and a general practical philosophy in the both the Groundwork and the Mrongovius lectures. Logic, we are told, stands to metaphysics in the way that general practical philosophy stands to morals (GMS 4:390-391; V-Mo/Mron II 29:597): just as logic abstracts from specific objects of cognition and does not take into account a fully determinate picture of human reason and the discursive understanding, so does general practical philosophy abstract from particular objects of the will and the grounds of motivation. But if this parallel holds, then it will be worried that rejecting general practical philosophy jeopardizes the science of morals in much the way that metaphysics collapses if it does not have in its background the principle of non-contradiction. 37

Second, if there is no Hypothetical Imperative or norm of prudence included in an account of the hypothetical imperatives of skill and prudence-if there is, for example, no room for the command, to recall Hill's formulation, that we ought to pursue the means to our ends - then it seems that Kantianism is left be-

instrumental rationality, Kant cannot be read along these lines because he cannot accommodate the idea of a practically rational principle that is not reason giving. Instead, and as also referenced in Footnote 14, the late Kant is most plausibly read as doubting the very existence of non-moral norms or a Hypothetical Imperative, and thus removing any need to determine whether a wide or narrow scope interpretation of such an imperative is more defensible.

37. To elaborate and to give this objection a fair hearing, we can note the rather technical or terminological arguments that can be marshaled in its defense. To begin, Kant at points excludes general disciplines from philosophy on the grounds that a general discipline is neutral in a way that philosophical domains are not. For example, general logic will be excluded from philosophy because unlike transcendental logic, general logic is not limited to the objects of the understanding and instead concerns rules governing any type of thinking whatsoever. Because general logic is neutral in this manner, it cannot provide a system of concepts for rational cognition and thus cannot be considered a branch of philosophy. On this basis, one can argue that even though Kant does not discuss a general practical philosophy in the third Critique, it must be presupposed to exist just in the same way that general logic is presupposed by Kant's discussion of natural philosophy. It would also follow that "general practical philosophy" is absent from the third Critique only because the terms "general" and "philosophy" are in tension with one another. Just as general logic is supposed to be more a propaedeutic to metaphysics or a theory of cognition than a branch or domain of philosophy itself, so, it may seem, there is a general or allgemeine practical propaedeutic to moral philosophy or to those "special [besondere] practical principles" Kant discusses in the third Critique.

Ergo • vol. 5, no. 11 2018 
reft of the resources needed to develop an adequate account of practical reason and unreason. In cases where an agent sets an end but fails to seek the means, or cases where an agent fails to secure the means to happiness, are there any conceptual resources that can be brought to bear, besides those that would describe naturalistically the technical failure exhibited?

Kant's response to these worries is neither as systematic nor as thorough as it should be. But we can nonetheless get at least some indication of what resources and arguments in Kant's mature writings can be leveraged to address them.

Though the mature Kant disputes that there are generic, non-moral principles governing the rightful determination of the will, it is not difficult to see why this doesn't put us adrift in the manner that a metaphysician would be without principles of logic. For while Kant will not allow a foundational norm of prudence or instrumental reason, he permits - in fact, he demands - that concerns of efficacy and happiness to a significant extent guide action.

This is made obvious throughout numerous texts, and the third Critique is no exception. The pursuit of what we must judge as nature's final end - the highest good - requires both that we tend to the happiness of all and that we be mindful of the empirical conditions under which such happiness is likely to come about. And, Kant appears to think, the presence of the moral law as the starting point in these efforts will prevent them from displaying the futility they would otherwise spiral into. A culture of skill would on its own lead to massive, unintended social inequality, but this propensity is curbed when civic and cosmopolitan institutions on a secure ethico-political footing are introduced (KU 5:432-433). Similarly, it is reasonable to think that the disappointment Kant described as clouding the attainment of happiness will dissipate, at least partly, in a moral context. While boredom, dissatisfaction, and emptiness result when happiness is treated as a final or ultimate end, Kant never expresses a worry that these threats will remain when happiness emerges as a component of the highest good and is "produced through the virtuous exercise of human freedom" (Guyer 2005: 301, original emphasis). Finally, and most to the point, it is the moral law itself - not some other law of reason - that commands us to have influence on the realm of nature and to make its ends "real" in the sensible world (KU 5:176).

So while the metaphysician without recourse to logic will not be able to adequately cognize the world, people can act well even without a general practical philosophy and even if no non-moral norms are immediately present within the will. They can do so because the moral determination of the will itself determines the extent to which happiness and instrumental success are rationally necessary. That is, while Kantians generally argue that it is prima facie rational and necessary to pursue the means to one's ends so long as those ends or the req- 
uisite means do not conflict with the moral law, ${ }^{38}$ the connection I am outlining between instrumental, prudential, and moral reason presents the connection as moving in the opposite direction. The demands of instrumental and prudential reason are not checked by moral demands; rather, moral reason will generate a need - its own need - for instrumental and prudential rationality. 39

And, post-third Critique, this account of non-moral norms runs implicitly throughout other writings from Kant. Take a text like the Anthropology, where Kant both refuses to offer a systematic account of the binding nature of instrumental and prudential norms and yet gives examples of instrumental and prudential unreason..$^{4}$ The interpretation of non-moral imperatives I have developed

38. We may recall not only that Wood and Hill ascribed to this view but also that Timmermann ultimately made a significant concession to it as well. See Section 2.

39. As we may recall from earlier in this article, Kant argues at the outset of the Introductions to the third Critique that practical and theoretical philosophy are distinct because each has its own set of objects-either morals, or objects of nature-and its own way of conceptualizing the laws that govern these objects. And though it may initially appear that Kant blurs this distinction when he allows moral reason to have its own need for instrumental efficacy and prudential success, his dualism between theoretical and practical philosophy nonetheless remains intact. Two points are relevant. First, recall from a moment ago the idea that the happiness that emerges as a component of the highest good is "produced through the virtuous exercise of human freedom" (Guyer 2005: 301). The happiness we seek at the behest of the moral law is, as Guyer's language indicates, a different thing or object from the happiness we seek when we tend only to its status as an assertoric, naturally necessary end or when we believe, incorrectly, that we have reason to care about it independent of morality. Second, we might take a cue from Kolodny's own work regarding the myth of instrumental rationality, since, as mentioned in Footnote 36, his view has some affinity with that proposed by Kant in the third Critique. Kolodny at points describes-evocatively, and beautifully - instrumental requirements in terms of the "shadow" cast by substantive normative principles (2005: 523; 2008: 390). We mistakenly believe that instrumental constraints are normative on their own but in fact this is illusory; what are really seeing is the "shadow" of those legitimate normative demands operating in the background. Now, this "shadow" metaphor can only be applied to Kant to a limited extent, since there is no clear indication that Kant would find every case of means-end failure as, invariably, a matter of a moral concern. Nonetheless, the metaphor is instructive. The metaphor helps explain not only why, and as discussed in Footnote 19, we are vulnerable to the illusion that instrumental constraints are normative on their own. It also explains why happiness and instrumental success must, when referenced by a practical philosopher, be thought as gaining normative significance only from the "shadow" cast by the moral law. That is, in those cases where prudence and skill become, in accordance with the moral law's demands, normatively relevant to the human being, "the concept that gives the rule to the causality of the will" is still a concept of freedom (KU 5:172; see also Section 4). With these observations, we can be confident that as we gather further insights into Kant's revised approach, he will not abandon but instead lend nuance to his account of what practical philosophy is and how its objects and laws are distinct from those within a philosophy of nature or a theoretical philosophy. I thank the anonymous reviewer who prompted me to discuss this issue.

40. For instance, and as widely known, Kant discusses in the Anthropology agents who suffer from passions (Leidenschaften), which are those subjective states in which certain ends preoccupy a person even though they lack the potential to contribute to her non-moral end of happiness (Anth 7:266), as well as individuals thwarted by affects (Affekten), which are rash urges that can disrupt instrumental action by overtaking a person (Anth 7:252). 
explains how to approach this juxtaposition. One can investigate such examples within a thoroughly naturalistic or empirical theory of human behavior, ${ }^{41}$ and one can also search for moral grounds on which to assess these defects. What we cannot do, according to the third Critique, is profess to have grounds for rational yet non-moral criticism of such individuals. If some action, or inaction, that fails to promote happiness or secure the means to a given end deserves criticism, exhortation, or some other negative reactive attitude, that can only be because the moral law itself grounds, in at least this case, concerns regarding imprudent or instrumentally deficient volition. ${ }^{42}$

\section{Acknowledgments}

Much earlier versions of this paper were presented at Georgia State University, the 2011 Felician Ethics conference, and the Second Biennial North American Kant Society Meeting at Cornell University. I am grateful to the audiences for their feedback and criticism, and would like to acknowledge Ben Vilhauer in particular for expressing enthusiasm about this project. Mavis Biss and Krista Thomason also provided helpful comments as I revised this paper in summer 2016. Finally, I wish to thank the anonymous reviewers selected by Ergo for their prompt and excellent feedback.

\section{Abbreviations}

$\begin{array}{ll}\text { Anth } & \text { Anthropology from a Pragmatic Point of View } \\ \text { EEKU } & \text { First Introduction to the Critique of the Power of Judgment } \\ \text { GMS } & \text { Groundwork of the Metaphysics of Morals } \\ \text { KpV } & \text { Critique of Practical Reason } \\ \text { KrV } & \text { Critique of Pure Reason } \\ \text { KU } & \text { Critique of the Power of Judgment } \\ \text { MS } & \text { Metaphysics of Morals } \\ \text { Refl } & \text { Reflexionen } \\ \text { UD } & \text { Inquiry Concerning Principles of Natural Theology and Morality }\end{array}$

41. A naturalistic theory of human behavior is not-at least for Kant-one that insists on offering a reductivist view of states of mind like desires, intentions, and beliefs. A naturalistic or empirical view must admit of no other causal relationship between these states than a mechanical or deterministic one, but this does not entail reductivism. On this point, see Frierson (2005: 17).

42. At this point, the only remaining argument in favor of preserving a general practical philosophy is a strictly architectonic one. One would have to think it necessary to preserve symmetry with, for example, general and special logic and argue, on this basis, that we must keep a general practical philosophy alongside those special principles of freedom that form a moral philosophy. 


$\begin{array}{ll}\text { V-Mo/Collins } & \text { Moral Philosophy: Collins' Lecture Notes } \\ \text { V-Mo/Mron II } & \begin{array}{l}\text { Morality According to Prof. Kant: Mrongovius's Second Set of } \\ \text { Lecture Notes }\end{array} \\ \text { V-MS/Vigil } & \text { Kant on the Metaphysics of Morals: Vigilantius's Lecture Notes }\end{array}$

\section{Bibliography}

Allison, Henry (2011). Kant's Groundwork for the Metaphysics of Morals: A Commentary. Oxford University Press. https://doi.org/10.1093/acprof:oso/9780199691531.001.0001

Bacin, Stefano (2015). Kant's Lectures on Ethics and Baumgarten's Moral Philosophy. In Lara Denis and Oliver Sensen (Eds.), Kant's Lectures on Ethics: A Critical Guide (1533). Cambridge University Press. https://doi.org/10.1017/CBO9781139567527.004

Broome, John (2007). Wide or Narrow Scope? Mind, 116(462), 359-370. https://doi. org/10.1093/mind/fzm359

Brunero, John (2010). The Scope of Rational Requirements. Philosophical Quarterly, 6o(238), 28-49. https://doi.org/10.1111/j.1467-9213.2008.596.x

Cramer, Konrad (1972). Hypothetische Imperative. In Manfred Reidel (Ed.), Rehabilitierung der praktischen Philosophie (Band 1, 159-212). Rombach.

Frierson, Patrick (2005). Kant's Empirical Account of Human Action. Philosopher's Imprint, 5(7), 1-34.

Guyer, Paul (2005). Kant's System of Nature and Freedom: Selected Essays. Oxford University Press. https://doi.org/10.1093/acprof:oso/9780199273461.001.0001

Hill, Thomas (1973). The Hypothetical Imperative. Philosophical Review, 82(4), 429-450. https://doi.org/10.2307/2183709

Hills, Alison (2006). Kant on Happiness and Reason. History of Philosophy Quarterly, 23(3), 243-261.

Kain, Patrick (2003). Prudential Reason in Kant's Anthropology. In Brian Jacobs and Patrick Kain (Eds.), Essays on Kant's Anthropology (230-265). Cambridge University Press.

Kant, Immanuel (1900-). Kants gesammelte Schriften (Akademie der Wissenschaften, Ed.). Walter De Gruyter (formerly Georg Reimer).

Kant, Immanuel (1914). Werke Band V (Ernst Cassirer, Ed., in collaboration with Hermann Cohen, Artur Buchenau, Otto Buek, Albert Görland, B. Kellermann). Bruno Cassirer.

Kant, Immanuel (1992). Inquiry Concerning Principles of Natural Theology and Morality (David Walford, Trans.). In David Walford with Ralf Meerbote (Eds.), Theoretical Philosophy: 1755-70 (243-275). Cambridge University Press.

Kant, Immanuel (1996a). Critique of Practical Reason (Mary J. Gregor, Trans.). In Mary J. Gregor (Ed.), Practical Philosophy (137-271). Cambridge University Press.

Kant, Immanuel (1996b). Groundwork of the Metaphysics of Morals (Mary J. Gregor, Trans.). In Mary J. Gregor (Ed.) Practical Philosophy (41-108). Cambridge University Press.

Kant, Immanuel (1996c). Metaphysics of Morals (Mary J. Gregor, Trans.). In Mary J. Gregor (Ed.), Practical Philosophy (363-603). Cambridge University Press.

Kant, Immanuel (1996d). Practical Philosophy. Mary J. Gregor (Ed.). Cambridge University Press. 
Kant, Immanuel (1997a). Kant on the Metaphysics of Morals: Vigilantius's Lecture Notes (Peter Heath, Trans.). In Peter Heath and J. B. Schneewind (Eds.), Lectures on Ethics (249452). Cambridge University Press.

Kant, Immanuel (1997b). Moral Philosophy: Collins' Lecture Notes (Peter Heath, Trans.). In Peter Heath and J. B. Schneewind (Eds.), Lectures on Ethics (37-222). Cambridge University Press.

Kant, Immanuel (1997c). Morality According to Prof. Kant: Mrongovius's Second Set of Lecture Notes (selections). (Peter Heath, Trans.). In Peter Heath and J. B. Schneewind (Eds.), Lectures on Ethics (223-248). Cambridge University Press.

Kant, Immanuel (1998). Critique of Pure Reason. Paul Guyer and Allen W. Wood (Eds. and Trans.). Cambridge University Press.

Kant, Immanuel (2000). Critique of the Power of Judgment. Paul Guyer and Eric Matthews (Eds. and Trans.). Cambridge University Press.

Kant, Immanuel (2007). Anthropology from a Pragmatic Point of View (Robert B. Louden, Trans.). In Günther Zöller and Robert B. Louden (Eds.), Anthropology, History, and Education (231>-429). Cambridge University Press.

Kiesewetter, Benjamin (2017). The Normativity of Rationality. Oxford University Press. https://doi.org/10.1093/oso/9780198754282.001.0001

Kolodny, Niko (2005). Why Be Rational? Mind, 114(455), 509-563. https://doi.org/10.1093/ mind/fzi509

Kolodny, Niko (2007). How Does Coherence Matter? Proceedings of the Aristotelian Society, 107(3), 229-263. https://doi.org/10.1111/j.1467-9264.2007.00220.x

Kolodny, Niko (2008). The Myth of Practical Consistency. European Journal of Philosophy, 16(3), 366-402. https://doi.org/10.1111/j.1468-0378.2008.00325.x

Korsgaard, Christine (1997). The Normativity of Instrumental Reason. In Garrett Cullity and Berys Gaut (Eds.), Ethics and Practical Reason (215-254). Oxford University Press.

Lee, Seung-Kee (2012). Self-Determination and the Categories of Freedom in Kant's Moral Philosophy. Kant-Studien, 103(3), 337-350. https://doi.org/10.1515/kant-2012-0022

Lord, Errol (2011). Violating Requirements, Exiting from Requirements, and the Scope of Rationality. Philosophical Quarterly, 61(243), 392-399. https://doi.org/10.1111/j.14679213.2010.688.x

Ludwig, Bernd (1988). Kants Rechtslehre. Meiner.

Meld Shell, Susan (2003). Kant's 'True Economy of Human Nature': Rousseau, Count Verri, and the Problem of Happiness. In Brian Jacobs and Patrick Kain (Eds.), Essays on Kant's Anthropology (194-229). Cambridge University Press.

Papish, Laura (in press). Kant on Evil, Self-Deception, and Moral Reform. Oxford University Press.

Pollok, Konstantin (2007). 'Wenn Vernunft volle Gewalt über das Begehrungsvermögen hätte' - Über die gemeinsame Wurzel der Kantischen Imperative. Kant-Studien, 98(1), 57-80. https://doi.org/10.1515/KANT.2007.003

Raz, Joseph (2005). The Myth of Instrumental Rationality. Journal of Ethics and Social Philosophy, I(1), 2-28.

Schroeder, Mark (2004). The Scope of Instrumental Reason. Philosophical Perspectives, 18(1), 337-364. https://doi.org/10.1111/j.1520-8583.2004.00032.x

Schroeder, Mark (2005). The Hypothetical Imperative? Australasian Journal of Philosophy, 83(3), 357-372. https://doi.org/10.1080/00048400500191958 
Schwaiger, Clemens (1999). Kategorische und andere Imperativen: Zur Entwicklung von Kants praktischer Philosophie bis 1785 . Frommann-Holzboog.

Shpall, Sam (2013). Wide and Narrow Scope. Philosophical Studies, 163(3), 717-736. https:// doi.org/10.1007/s11098-011-9841-z

Stange, Carl (1900). Der Begriff der 'hypothetischen Imperative' in der Ethik Kants. KantStudien, 4(1), 232-247. https://doi.org/10.1515/kant.1900.4.1-3.232

Timmermann, Jens (2007). Kant's Groundwork of the Metaphysics of Morals: A Commentary. Cambridge University Press. https://doi.org/10.1017/CBO9780511487316

Way, Jonathan (2010). The Normativity of Rationality. Philosophy Compass, 5(12), 10571068. https://doi.org/10.1111/j.1747-9991.2010.00357.x

Wood, Allen (1999). Kant's Ethical Thought. Cambridge University Press. https://doi. org/10.1017/CBO9781139173254

Wood, Allen (2013). Kant on Practical Reason. In Mark Timmons and Sorin Baiasu (Eds.), Kant on Practical Justification: Interpretive Essays (57-86). Oxford University Press. https://doi.org/10.1093/acprof:oso/9780195395686.003.0004

Wood, Allen (2014). The Free Development of Each: Studies on Freedom, Right, and Ethics in Classical German Philosophy. Oxford University Press. https://doi.org/10.1093/acprof: oso/9780199685530.001.0001

Zammito, John (1992). The Genesis of Kant's Critique of Judgment. University of Chicago Press.

Zuckert, Rachel (2007). Kant on Beauty and Biology: An Interpretation of the Critique of Judgment. Cambridge University Press. https://doi.org/10.1017/CBO9780511487323 